\title{
Experience of Introduction of the Online Course in Biology for Pharmacy Students in Ukraine
}

\author{
Filiptsova Olga*1, Naboka Olga ${ }^{1}$, Gazzavi-Rogozina Lyudmila', Dyomina Yevgeniya1, Galiy Larisa² \\ ${ }^{1}$ National University of Pharmacy, Department of Biology, Ukraine, Kharkov, UKRAINE. \\ ${ }^{2}$ National University of Pharmacy, Department of Pharmaceutical Marketing and Management, Ukraine, Kharkov, UKRAINE.
}

\begin{abstract}
Introduction: Distance learning is getting more and more popular all over the world and more recently it expanded into Ukraine. The objective of work was to clarify the experience of development and principles of the on-line course "Biology and Genetics Principles" for pharmacy students in one of the oldest universities of Ukraine - National University of Pharmacy. Methods: The study was conducted using the method of observation and analysis using modern IT technologies. Analysis was conducted based on the material of the current course "Biology and Genetics Principles" which is taught to the 1st year students of the major "Pharmacy" and was approved on 87 members of the audience within 2015-2016 and 2016-2017 academic years. Assessment: on-line course "Biology and Genetics Principles" was developed based on the platform Moodle; it consists of training, communication and control modules and is taught for a period of 12-23 days. Was exposed high satisfaction of the students with learning experience in the framework of the course ( 5 points under the 5 -point scale) and quality of communication with the tutor and the group (4.9 points under the 5-point scale). Discussion: The developed system can serve not only for the needs of the educational process, but also as the base for scientific research of the efficiency of distance learning in the process of training of specialists, particularly, in the pharmaceutical industry.
\end{abstract}

Key words: Distance Learning, Ukraine, Pharmacy Students, Biology, Course Structure/ Assessments.

\section{INTRODUCTION}

The development of modern technologies has allowed to open a new promising education system for students, in particular, for the future pharmacists-distance learning. Distance learning uses the basic principles of full-time and part-time education. At the same time it offers new advanced features: use of the Internet to get access to the learning materials on-line, an interactive communication between the students and the lecturer, a variety of multimedia approaches, etc. Computer tools provided interactivity of all participants of an educational process. Structuring, consistency and systematic nature of educational process is provided by a modular form of on-line course.

Due to the number of features (concurrency, synchronization, profitability, internationality), distance learning is getting more and more popular. ${ }^{1}$ Thus, in 2003, 81\% of all higher education institutions in the world were offering at least one completely on-line course or a hybrid course, and in 2005 , number of such educational institutions increased for $8 \%$ more. $^{2}$ In addition, on-line format is extends not only to the university students, but also to the postgraduate students. ${ }^{3}$ Taking into account the problems of uninterrupted Internet access to the distance areas of the globe, in certain cases in the process of development of distance learning courses, is assumed creation of applications which can work off-line. For example, in Brazil, in one of the universities there was developed similar 28 applications. ${ }^{4}$ Distance learning in teaching of natural sciences, including, biological, medical and pharmaceutical sciences is rapidly developing.
Submission Date: 27-02-2017; Revision Date: 10-04-2017; Accepted Date: 13-07-2017

DOI: 10.5530/ijper.51.4.79 Correspondence: Filiptsova O.V., National University of Pharmacy, Department of Biology, Ukraine, Kharkov Ukraine, 61002, Kharkov, Pushkinska str., 53, National University of Pharmacy \& National University of Pharmacy, Head of Biology Department, Professor, Doctor of Biological Sciences Phone no: +38098409910 E-mail: philiptsova@yahoo. com

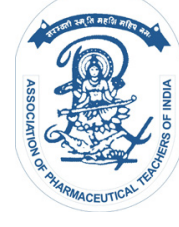

www.ijper.org 
In the universities of the world there are on-line courses in biology and related subjects, such as "Biology Principles", "Principles of Evolution, Ecology and Behavior", "Biochemistry", "Genetics", "Molecular Biology", "Cell Biology and Biology Systems", "Gene Expression in Eukaryotes", "Computational Molecular Biology", "Introduction to the Study of the Genome", etc. ${ }^{5}$ When developing the distance learning courses with a focus on the specific categories of users, should be taken into account their professional needs. For example, when developing courses in Genetics for the health workers practicing it, among other things, there were included clinical cases containing ethical, theoretical and practical information. ${ }^{6}$ Some subjects related to Biology, can be taught in a fully virtual format. For example, is illustrated the effectiveness of on-line learning of bio informational subjects connected with the collection, storage, processing and analyzing of large amounts of biological and medical information. Is marked the Finnish experience which offered two distance learning courses a few years ago: "Introduction to bioinformatics" and "Bioinformatics in Functional Genomics". Nearly 400 students from the different universities have successfully mastered these courses exclusively on-line. ${ }^{7}$ Some medical subjects generally require the compulsive and inescapable practical support. They are designed as a supplement to the existing courses, although do not always provide gaining of a definite qualification. As an example can be taken the on-line course in Applied Oncology. It was created in 2004 as a pilot project and it was applied in 7 countries of Asia, Africa and Latin America. First year the course was downloaded about 1100 times after it was put on-line. Later, it was significantly updated. ${ }^{8}$

The objective of work was to highlight the experience of development and principles of on-line course "Biology and Genetics Principles" in the National University of Pharmacy. This is one of the oldest universities in Ukraine. The specialists of different professions for domestic and international pharmaceutical job market (Iraq, Lebanon, Morocco, Egypt, Nigeria, Ethiopia, Ghana, Algeria, Turkey, Poland, Belarus, etc.) are being trained here. The foundational specialty "Pharmacy" is much in demand. Besides this specialty, students may choose other courses on the following specialties: Industrial Pharmacy, Clinical Pharmacy, Laboratory Diagnostics, Biotechnology, Cosmetic Technology, etc. However, currently in the National University of Pharmacy the traditional (full-time, part-time) and distance learning is combined only for the specilaty "Pharmacy".

\section{MATERIALS AND METHODS}

The study was conducted by observation method and analysis using modern IT technologies. All the distance learning courses of the National University of Pharmacy can be found at http://pharmel.kharkiv.edu/moodle/ and are available for the students and lecturers having access to a specific educational subject via login and password. The analysis was conducted on the material of the current course "Biology and Genetics Principles", which is taught to the 1st year students of the specialty "Pharmacy". The course was developed at the Department of Biology of the National University of Pharmacy and approved on 87 students within 2015-2016 and 2016-2017 academic years.

\section{ASSESSMENT AND DISCUSSION}

On-line course "Biology and Genetics Principles" started its development in the 2012-2013 academic year. It took about 3 months. Over the next two years it was significantly updated and improved. As it is known, that constant updating is a feature of the most on-line courses. Thus, analysis of on-line courses in European schools showed that all platforms were constantly updated, were compatible and provided renewable use. ${ }^{9}$ In particular cases, on-line courses can be significantly updated and the number of modules can also be increased. ${ }^{8}$

According to the curriculum the students of specialty "Pharmacy" of "Master" degree of the National University of Pharmacy have 90 hours or 3 credits to study the educational subject "Biology and Genetics Principles". on-line course "Biology and Genetics Principles" was two times approved in 2015-2016 and 2016-2017 academic years on 87 students of the 1 st year. Structurally the subject contains 3 modules: "Introduction to biology, cell structure and development of a human", "Genetics Principles" and "Medical Parasitology Principles". It is clear, that structuring of biomedical sciences and division of them into the large number of modules makes the studies of the students in the courses much easier. For example, a course on Human Genetics for the students of the Department of Medicine and the Department of Natural Sciences at Marburg University consists of 5 modules: Cytogenetic, Chromosomal Aberrations, Formal Genetics, Basics of Molecular Diagnostics and Congenital Anomalies and Syndromes. ${ }^{1}$ A well-known on-line course in Applied Oncology and widely used in the world consists of 71 modules, that are directly related to the Pathology, Anatomy, Molecular Biology, Physical Basics of Imaging Tumors, Studying the Effects of Radiation on the Body, Meal Plan for Oncology Patients, Cancer Patients' Care, 
Economic Aspects of Treatment in Oncology, Statistical Data Processing, etc. ${ }^{8}$

on-line course "Biology and Genetics Principles" of the National University of Pharmacy has been developed on the basis of Moodle platform. As it is known, this platform provides new role of the lecturer and the student where the lecturer acts as a tutor. The tutor has the opportunity of on-line interaction with the students (consultations, video message, conference) taking into account their individual needs. Besides just learning, the student personally gains it and makes suggestions for improving the quality of the course. A significant advantage of this system is a variety of types of on-line learning, multilingualism, unlimited number of students, internal and external tests support, advanced reporting and assessment systems. Moodle has a simple and efficient web-interface. Students can edit their profiles, add photos and change personal and reference details (Figure 1). Each user can specify the local time (Figure 2). Moodle makes it possible to establish a sequence of receiving messages from other participants of the course (Figure 3).

The course "Biology and Genetics Principles" is structurally divided into several weeks. These weeks do not necessarily correspond to the duration of the week in a chronological sense. In a real-time on-line course of study is within 12-23 days depending on the particular category of students obtaining Master's degree in "Pharmacy". Thus, the minimum time (12 days) the course "Biology and Genetics Principles" attend those who already have a vocational medical education and study the educational subject as an optional. The maximum time (23 days) to study the educational subject is given to students who already have any other degree or have specialized secondary pharmaceutical education.

For the convenience of students at the beginning of the course are available: the information with details about the educational subject (presentation, introduction, grading system), as well as, the algorithm and training schedule, grading system, list of sources, glossary of the course, three auxiliary chats: introduction chat, news chat and tutor's and mutual assistance chat (Figure 4).

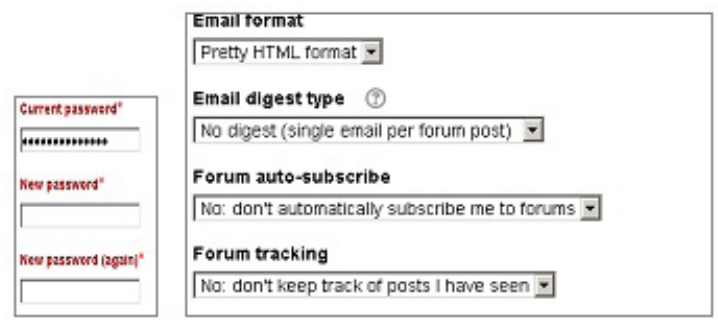

Figure 1: Profile editing.

\section{City/town}

Kharkov

\section{Select a country}

Ukraine

Timezone

UTC+2

\section{Preferred language}

English (en)

Figure 2: Local time setting.

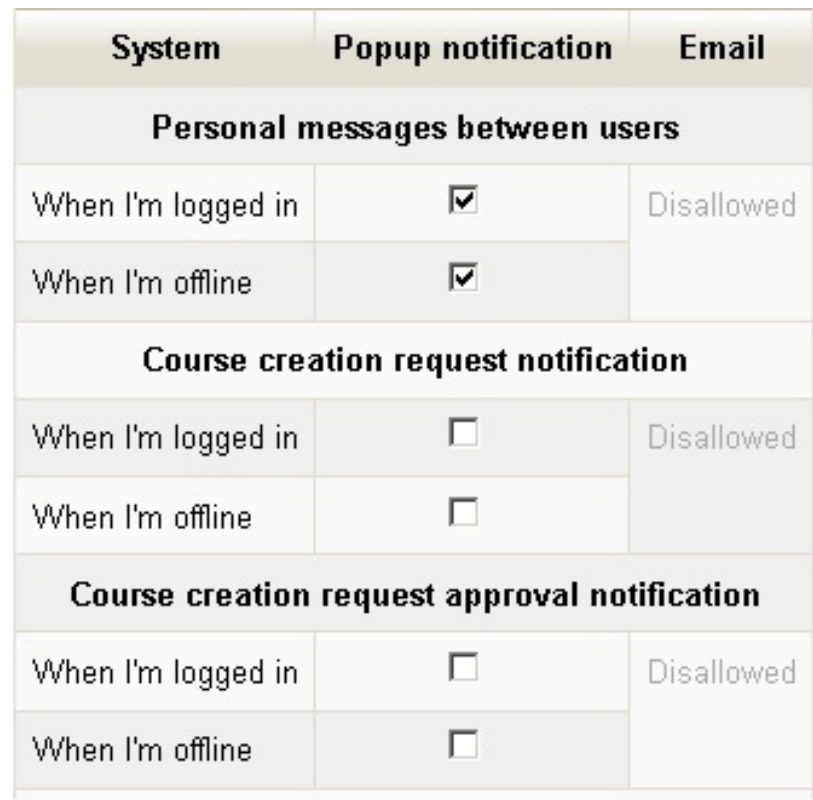

Figure 3: Message retrieval order setting.
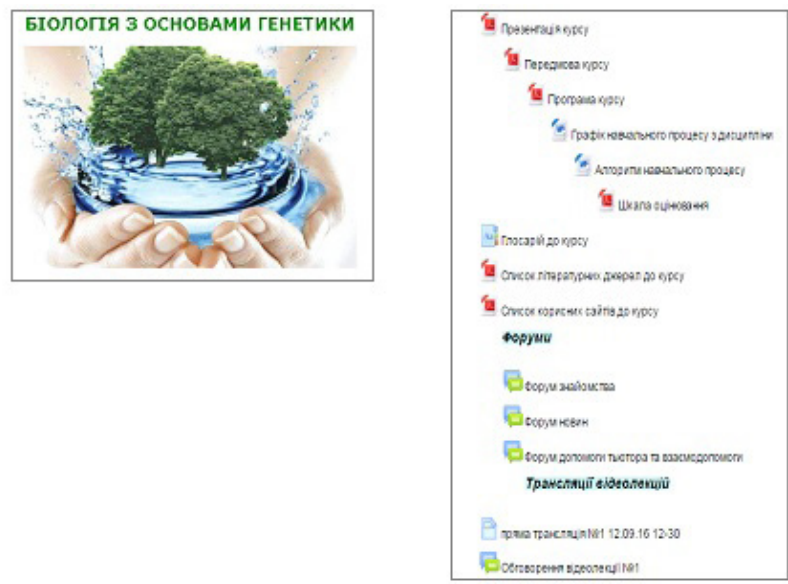

Figure 4: Introductory information about the course. 
Introduction chat enhances the students' communication skills and provides the establishment of psychological comfort during training.

Tutorials are presented in the form of audio lectures, practical training manual, tasks and examples of their solution (Figure 5).

Basic information material is presented in PDF files, so the students can download them for easy view. Additional content includes useful links that complete the lectures. Video lectures contribute to a more productive understanding of the information and additional contact with the lecturer (Figure 6).

The quality of students' knowledge is checked with the help of a number of control measures, namely, control questions, multiple-choice tests, practical work and participation in discussion forums (Figure 7). One study had shown, that as the quality control method most participants of the study preferred the multiple-choice tests and illustrated exercises, and in descending order of preference - interactive questions that assumed the conclusion of started expressions. ${ }^{3}$

The maximum grade that a student can get is 100 . In turn, the students' work within the estimated on-line course is assessed under 60-point scale for each topic. The system automatically calculates the average score and figures out rating (Figure 8).

At the final stage of training in the course "Biology and Genetics Principles" at the National University of Pharmacy at the face-to-face meeting the student has the opportunity to carry out certain pieces of practical tasks in the laboratory and form a final module control. For this final control assessment the student can get 40 points more out of 100. It should be noted that the hybrid on-line courses which provide on-line training and face-to-face communication can enhance student's performance. In particular, it is established, that parallel training in on-line courses and the presence at clinical encounters effectively complemented each other during the training of Australian third year medical students. ${ }^{10}$ Another research involving 29 professional American lecturers studied the effectiveness of a combined approach in teaching of Molecular Biology. Particular benefit in gaining theoretical knowledge was provided by video and multimedia animations, which in prospect more efficiently established themselves in a laboratory conditions during face-to-face contact of a student and a lecturer. ${ }^{11}$

The lecturer can assess the quality of knowledge on-line, comment on any work, inform a student about the mistakes and the ways to correct them. On-line course allows the lecturer to do a comprehensive analysis of
Тема 2

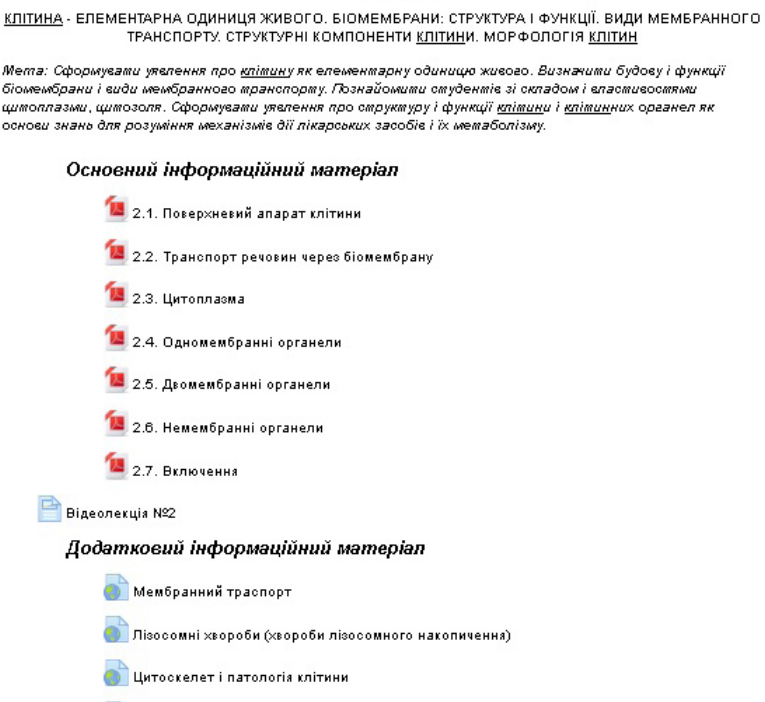

Figure 5: Typical layout of a page with a topic.

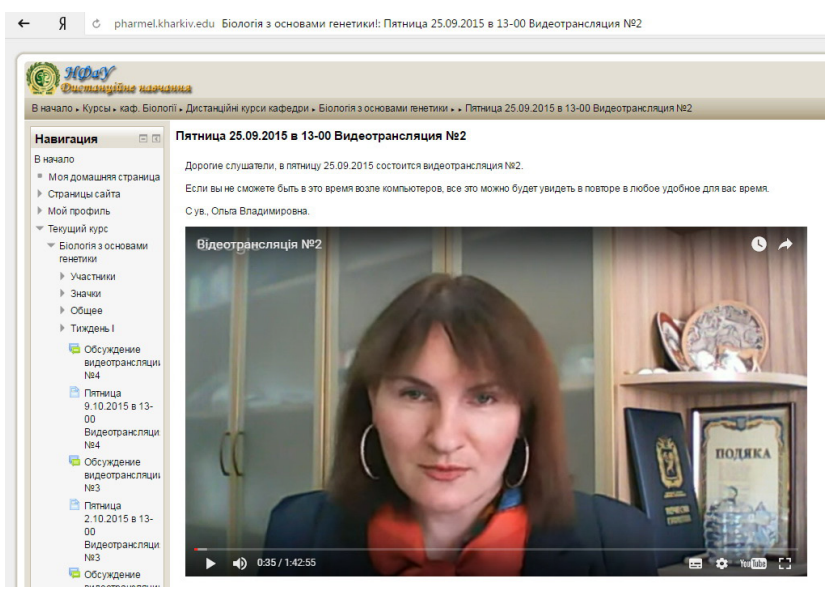

Figure 6: Video lecture in on-line course (photo with the courtesy of the co-author).

Збільшення об'єктиву мікроскопа становить $\times 40$, окуляра - $\times 15$. Яке загальне збільшення оптичної зистеми цього мікроскопу?

энберите один отве

$C_{a . \times 100 .}$

6. b. $\times 600$.

$C_{0 \times 200}$

$C_{\text {d. }} \times 300$.

C. $\times 400$.

Проверить

१равильнแй ответ: х600.

эерно

эалль эа эту попнтку: $1,00 / 1,00$

Figure 7: Example of multiple choice test.

time spent on classes, as well as the difficulties that have arisen among the students (Figure 9).

The lecturer has the opportunity to coordinate the students' work through tutor's and mutual assistance chat. News chat exercises a function of the virtual pin board where the lecturer informs the students about 


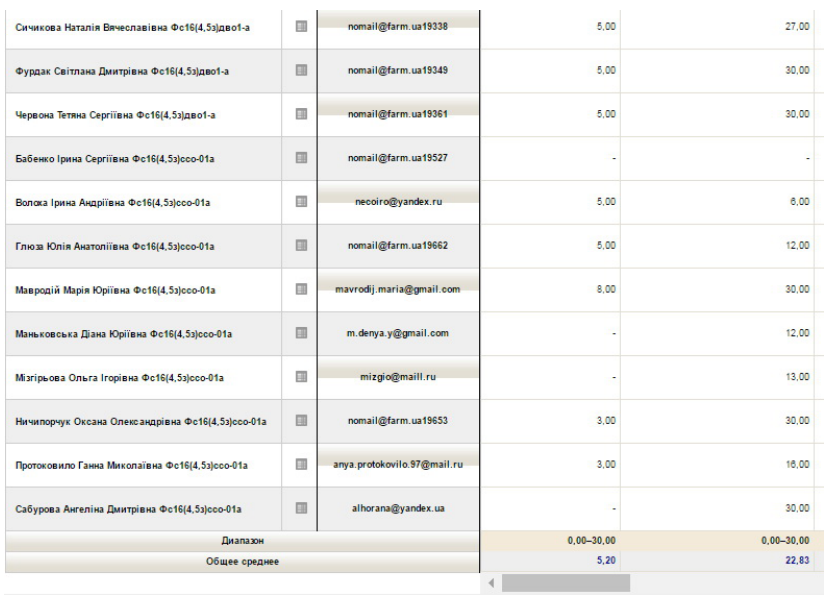

Figure 8: Details of students rating in the assessment source.

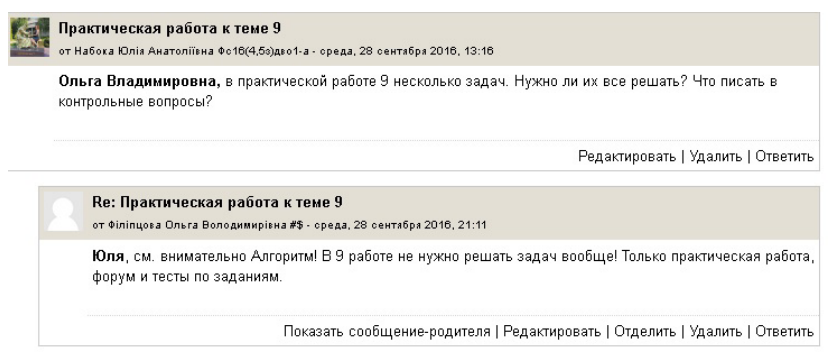

Figure 9: Example of lecturer's assistance to the student in the chat.

Время on-line 12 сен 2016 пОНЕДЕЛЬНИк

by Філіпцов Ольга Володимирівна \#8 - Sunday, 11 September 2016, 12:50 pm

Завтра я буду находиться в режиме on-line c 16 до 17.30. Также завтра будет видеобращение (12.30), которое можно будет смотреть в повторе, оно будет вывешено в 0-й неделе.

Figure 10: Message from the lecturer to the students about the time of video message and time of being on-line.

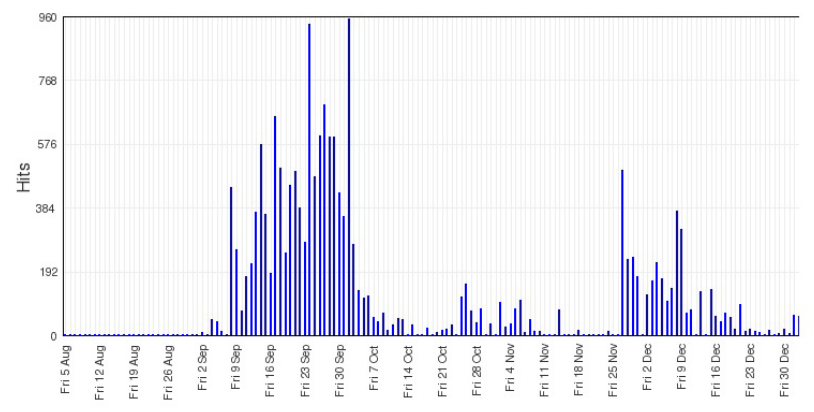

Figure 11: Schedule of user's activity.

the time of video lectures, tests, examinations, consultations, time of being on-line in the framework of the course, etc. (Figure 10).

The system allows to make a report on the activity of each user for a certain period (Figure 11). An important feature of the course is storage of student's files: in the system are stored all practical works performed, answers to test questions, grades, posts to the chats.

Comparing the content of the on-line course "Biology and Genetics Principles" with filling of other biomedical courses in the world, can be traced both the presence and the absence of some common components that vary from course to course. Thus, the research of the experience of the eight European higher educational institutions revealed that in two cases there was an option of teleconferencing, in five of them the courses were presented in PDF and in four of them there was an option of on-line testing. ${ }^{9}$ on-line course in Oncology had modules with an interactive text information, illustrations and tasks for academic performance rating. ${ }^{8}$ In general, the developers of on-line courses are guided by some strategies at the conversion of subjects to on-line format. For example, when studying Physiology at the Perdiu University, in addition to similar or identical strategies of classical form of education (study of clinical cases, video and conceptual maps), on-line format offered additional academic methods (animation and virtual microscope). ${ }^{2}$ More and more attention in on-line formats attract virtual laboratories, example of which are the proteomics laboratories. In such programs is possible study of methods of proteomics, bioinformatics and molecular docking tools, and also their practical use on different biological specimens. ${ }^{12}$ In the University of British Columbia in Canada was developed and actively used over several years MEDICOL system, which represents a number of additional web resources for the students who study medicine. This resource represents the schedule, learning goals, handouts, graphics, links, tasks and assessment system for a number of biomedical courses. It provides the possibility of interaction of the students with each other and with the lecturer via e-mail and information board, there is also an option to send the students daily tasks.$^{13}$ In connection with the conversion of training courses to on-line format a recent problem is to raise motivation and for this purpose problem-oriented training is increasingly applied. In one of the studies this approach contributed to the extending away from the mechanical memorizing of information to the formation of a research thinking in students. ${ }^{14}$ One study examined the suggestions of the American physicians to the format of presenting information in on-line resources. It was found that the majority of respondents preferred to use printed text, converted into electronic format. Text in on-line mode with embedded interactive questions was much less attractive to read. Results of the study showed that $78 \%$ of physicians have access to the Internet resources at work and at home. Perception of information was positive due to 


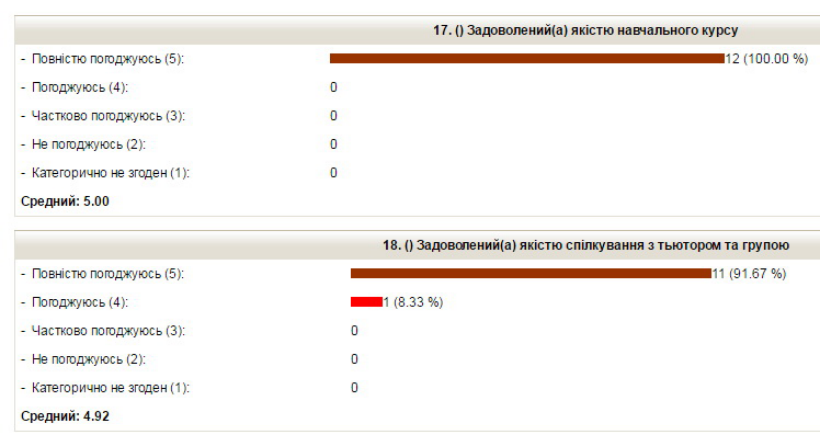

Figure 12: Quality assessment of on-line course by the students.

the ease of navigation and quality of interactive exercises and image quality. ${ }^{3}$

It should be noted that in all on-line courses of the National University of Pharmacy the board made an anonymous on-line questionnaire survey of the students. In particular, students of the courses were offered to answer 18 questions. Each question involved the selection of the following answers: "strongly agree", "agree", "partially agree", "disagree", "strongly disagree". Accordingly, depending on the selected question the answer was evaluated from 5 to 1 point (Figure 12).

The findings of questioning of the students are very encouraging. In particular, from the 31 students for whom the subject "Biology and Genetics Principles" was compulsory in the 2016-2017 academic years, 12 participated in the study. Without exception, respondents rated the learning experience in that course with the highest mark. As for the quality of communication with the lecturer and the group, $92 \%$ of students fully agreed that this factor also deserved the highest praise. A similar study that was conducted among US medical students had shown that on-line interaction between students and lecturers and students with each other was positively evaluated by approximately $81 \%$ and $80 \%$ of the respondents respectively. ${ }^{15}$

\section{CONCLUSION}

Distance learning is popular all over the world and recently it expanded into Ukraine. This learning approach in teaching of natural sciences, including, biological, medical and pharmaceutical sciences is rapidly developing. We clarified the experience of development and principles of the on-line course "Biology and Genetics Principles" for pharmacy students in one of the oldest universities of Ukraine - National University of Pharmacy. Analysis was conducted based on the material of the current course "Biology and Genetics Principles". On-line course "Biology and Genetics Principles" was developed based on the platform Moodle. It consists of training, communication and control modules and is taught for a period of 12-23 days. Was exposed high satisfaction of the students with learning experience in the framework of the course and quality of communication with the tutor and the group. Next we plan to compare the academic success of students in this study format and in the traditional (full-time and part-time) learning.

\section{ACKNOWLEDGEMENT}

The authors are thankful to the staff of the Pharmacy Faculty No.2 of National University of Pharmacy and to the staff of the Center of Distance Learning Technologies of National University of Pharmacy for providing support in receiving all necessary data for analysis.

\section{CONFLICT OF INTEREST}

The authors declare that they have no conflicts of interest.

\section{ABBREVIATION USED \\ PDF: Portable Document Format.}

\section{REFERENCES}

1. Oeffner F, Schäfer C, Fritz B, Fuchs AL, Rauschendorf A, König R, Kunz J. Interactive e-learning courses in human genetics: usage and evaluation by science and medical students at the faculty of medicin. GMS Zeitschrift für Medizinische Ausbildung. 2011;28(3). PMid:21866240 PMCid:PMC3159195.

2. Ertmer PA, Nour AY. Teaching basic medical sciences at a distance: strategies for effective teaching and learning in internet-based courses. Journal of veterinary medical education. 2007;34(3):316-24. https://doi. org/10.3138/jvme.34.3.316.

3. Burgess G, Holt A, Agius R. Preference of distance learning methods among post-graduate occupational physicians and hygienists. Occupational Medicine. 2005;55(4):312-8. https://doi.org/10.1093/occmed/kqi117; PMid:15982981.

4. Oliveira AE, França RM, Castro JE, Baesse DC, Maia MF, et al. The Use of Applications in Distance Education Specialization Course as a Support Tool for Students Living in Remote Areas Without Internet. Studies in health technology and informatics. 2014;216:847-51.

5. Searls DB. An online bioinformatics curriculum. PLoS Comput Biol. 2012; 8(9):e1002632. https://doi.org/10.1371/journal.pcbi.1002632; PMid:23028269 PMCid:PMC3441465

6. Gresty $\mathrm{K}$, Skirton $\mathrm{H}$, Evenden A. Addressing the issue of e-learning and online genetics for health professionals. Nursing \& health sciences. 2007;9(1):14-22. https://doi.org/10.1111/j.1442-2018.2007.00296.x; PMid:17300540.

7. Tolvanen $M$, Vihinen $M$. Virtual bioinformatics distance learning suite. Biochemistry and Molecular Biology Education. 2004;32(3):156-60. https:// doi.org/10.1002/bmb.2004.494032030336; PMid:21706714.

8. Barton MB, Thode RJ. Distance learning in the Applied Sciences of Oncology. Radiotherapy and Oncology. 2010;95(1):129-32 https://doi.org/10.1016/j. radonc.2010.02.011; PMid:20223541. 
Messaoudi T, Bodin F, Diaz JH, Ichihara S, Fikry T, et al. Evaluation of a new eLearning platform for distance teaching of microsurgery. Chirurgie de la main. 2015;34(3):109-12. https://doi.org/10.1016/j.main.2015.02.002; PMid:25964220.

10. Selzer R, Tallentire VR, Foley F. The effects of utilizing a near-patient e-learning tool on medical student learning. Medical teacher. 2015;37(6):558-65. https://doi.org/10.3109/0142159X.2014.955842; PMid:25189190.

11. Boulay R, Parisky A, Leong P. Designing online resources in preparation for authentic laboratory experiences. The international journal of design education. 2013;6(2):57. https://doi.org/10.18848/2325-128X/CGP/ v06i02/38402; PMid:24319698 PMCid:PMC3854946.
12. Ray S, Koshy NR, Reddy PJ, Srivastava S. Virtual Labs in proteomics: New E-learning tools. Journal of proteomics. 2012;75(9):2515-25. https://doi. org/10.1016/j.jprot.2012.03.014; PMid:22484059.

13. Broudo M, Walsh C. MEDICOL: online learning in medicine and dentistry. Academic Medicine. 2002;77(9):926-7. https://doi.org/10.1097/00001888200209000-00028; PMid:12228095.

14. Tichon JG. Problem-based learning: a case study in providing e-health education using the Internet. Journal of telemedicine and telecare. 2002;8(3 suppl):66-8

15. Corum KA, Gadbury-Amyot CC, Johnson K, Strait TM. US dental hygiene faculty perceptions of learner outcomes in distance education courses. Journal of dental education. 2014;78(4):530-40. PMid:24706682.

\section{PICTORIAL ABSTRACT}

On-line course "Biology and
Genetics Principles",
National University of
Pharmacy, Kharkov,
Ukraine

\section{About Authors}

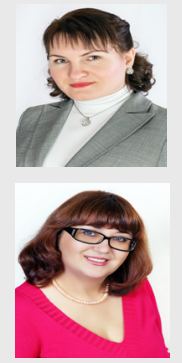

Olga Filiptsova: Head of Biology Department of the National University of Pharmacy (Ukraine), Doctor of Biological Sciences, Professor. Area of interest: Human Genetics, Pharmacogenetics, Behavior Genetics.

Olga Naboka: Dean of Medical and Pharmaceutical Faculty of the National University of Pharmacy (Ukraine), Doctor of Biological Sciences, Professor of Biology Department. Area of interest: Biochemistry, Pharmacology.

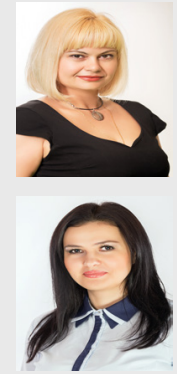

Lyudmila Gazzavi-Rogozina: Associate Professor of Biology Department of the National University of Pharmacy (Ukraine), Candidate of Agriculture Sciences. Area of interest: Medical Parasitology.

Yevgeniya Dyomina: Assistant of Biology Department of the National University of Pharmacy (Ukraine), Candidate of Medical Sciences. Area of interest: Otolaryngology.

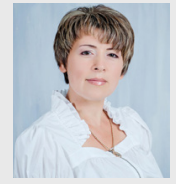

Larisa Galiy: Dean of Pharmaceutical Faculty No.2 of the National University of Pharmacy (Ukraine), Doctor of Pharmaceutical Sciences, Associate Professor of Pharmaceutical Marketing and Management Department. Area of interest: Personal Management in Pharmacy.

Cite this article: Filiptsova OV, Naboka OI, Gazzavi-Rogozina LV, Dyomina Ye V, Galiy LV. Experience of Introduction of the Online Course in Biology for Pharmacy Students in Ukraine. Indian J of Pharmaceutical Education and Research. 2017;51(4):510-6. 